\title{
The Agents Orange and Purple Controversy on the Island of Guam
}

\author{
Alvin L. Young and Kristian L. Young* \\ A. L. Young Consulting Inc., Cheyenne, Wyoming, United States \\ *Email: youngrisk@aol.com
}

\begin{abstract}
This article examines the available documentation adduced by Vietnam-era veterans and others to support the allegation that Agents Orange and Purple were shipped to and used on Andersen Air Force Base, Guam, and that veterans stationed there during the Vietnam War Era were exposed to these military tactical herbicides. The documentation was further evaluated in the context of the extensive historical records on tactical herbicides retained in the National Archives and Records Administration and other archival repositories addressing the locations where shipment, storage, use, or burial of tactical herbicides occurred. The conclusion from the submitted documentation, all identified historical records and studies by the United States Agency for Toxic Substances and Disease Registry and Environmental Protection Agency is that no plausible scenarios of exposure to Agents Orange or Purple occurred at Anderson Air Force Base, Guam.
\end{abstract}

Keywords: Agent orange, agent purple, vietnam-era veterans, tactical and commercial herbicides, island of guam, korean conflict

\section{Introduction}

The Compensation Service of the Veterans Benefits Administration (VBA) of the United States Department of Veterans Affairs (DVA) has the responsibility for handling claims related to Agent Orange and other tactical herbicides used in Vietnam. Over the past few years, one of the sites or locations outside of Vietnam where Vietnam-era veterans claim exposure to Agent Orange was on the island of Guam. In 2005, a Board of Veterans Appeals decision (Citation \# 0527748) granted service connection for a disease (Type 2 Diabetes) due to Agent Orange exposure on Guam [1]. This decision has been widely disseminated on the Internet and is often referred to by Veteran claimants who served on Guam. BVA decisions do not establish legal precedents that Compensation Service must follow, but this decision is one that has apparently influenced some regional office determinations regarding Agent Orange exposure on Guam. Mitchell in 2012 claimed that Defense Department (DOD) records indicated that 5,000 drums of Agent Purple were stored on Guam in 1952 [2]. Most recently, in January 2017, A 68-year-old Air Force veteran, now suffering from cancers and auto-immune diseases, said he sprayed "hundreds of thousands of gallons" of the toxic herbicide Agent Orange on Guam while stationed at Andersen Air Force Base (AFB) in the 1960s and '70s, and perhaps some of that material may have been from old drums of Agent Purple. The veteran claimed that he was assigned to vegetation control while stationed at Andersen. He said he sprayed "two and three trailer full" of the herbicide a day "along the flight line, sidewalks, fences, fuel tank farms and barracks" at the base [3].

\section{$2 \quad$ Background}

Andersen AFB, Guam is now host to the $36^{\text {th }}$ Wing of the Air Mobility Command, United States Air Force (USAF). However, during and immediately after the Vietnam War Andersen AFB was a USAF Strategic Air Command Installation. At that time, Andersen AFB occupied 11,047 acres of porous limestone on a plateau about 600 feet above sea level at the northern end of the Island of Guam [4]. In November 1962, Typhoon Karen with winds of $200 \mathrm{mph}$ passed directly over the island and brought extensive destruction to the base. Much of the destroyed materials were burned and buried in a series of landfills. 
In April 1964, the first deployment of B-52s from the 95 ${ }^{\text {th }}$ Bomb Wing arrived at Andersen AFB. In June 1964, KC-135 Stratotankers assigned to Andersen Tanker Task Force were used to support combat operations in Vietnam. A formidable force was assembled at Andersen AFB through 1965 and support of B-52s and KC-135s increased continually until the peak in 1972, when more than 150 B52's and supporting tankers crews and support personnel pushed Andersen's military population past 15,000. Billeting at Andersen became over crowded, and "tent cities" were improvised quarters set up in open fields near the flight lines [4].

The logistical supplies required to support Andersen's mission during the Vietnam War were massive. With its huge fuel and munitions storage facilities and dual runways, Andersen AFB was an important forward-based logistics support center for forces deploying throughout Southeast Asia. Thousands of 55gallon drums were positioned to provide the required fuels, oils, lubricants, and solvents necessary to support multiple operations [4]. Vegetation control around base perimeters and runways was an important responsibility of the facility managers. Waste oils and other spent solvents were generated in large quantities requiring disposal in the landfills on and surrounding the base [4].

In January 2002, The Department of Health and Human Services' Agency for Toxic Substances \& Disease Registry (ATSDR) released "Public Health Assessment, Andersen Air Force Base, Yigo, Guam" [5]. ATSDR reported that 6 of 39 landfill sites contained, among other chemicals, measurable levels of dioxins. However, ATSDR concluded that: "No apparent public health hazards are associated with soil contamination at Andersen AFB." This conclusion was further supported based on analytical data provided in the 2003 US Environmental Protection Agency (EPA) Records of Decisions that established that the dioxins and furans found there were from emission residues, i.e., ash from pit burning, municipal incinerators and explosives [6].

A 7 May 2003 letter to Secretary of Defense Donald Rumsfeld from Congressman Lane Evans requested that the Department of Defense assess the allegation that veterans stationed on Guam, i.e., Andersen AFB, were exposed to Agent Orange, its associated dioxin contaminant, as well as Agents White and Blue during the Vietnam Era [7]. In a 23 September 2003 letter responding to Congressman Lane, the Office of the Under Secretary of Defense (Installations \& Environment - I\&E) reported that the Department had found no records of the use, storage, or testing of Agents Orange, Blue, or White on Guam [8]. However, it noted that in 1952, roughly 5,000 drums of Agent Purple were (allegedly) transported to Guam and stored there in anticipation of use on the Korean Peninsula. The herbicide was never used and was returned to the United States [8]. Moreover, in responding to the presence of the dioxins, the Under Secretary's letter noted that "The presence of dioxin contamination at a site does not necessarily indicate Herbicide Orange was used or stored at that site, i.e., the dioxins at sites referenced in the Public Health Assessment were associated with burned material." [Added note: In an email to staff of the Under Secretary of Defense (I\&E), dated 28 October 2009, from the Andersen AFB Base Restoration Program, Guam, stated: "The dioxin that was found at various restoration sites was associated with burned materials. When analysis is specific as to what chemical in the family of dioxins, it is listed as 2,3,7,8-TCDD-TEQ." . Dioxins generated by combustion differ from the dioxin contaminant in Agent Orange.

In April 2004, a private research firm, Innovest Strategic Value Advisors, Inc., published the report "Dow Chemical: Risks for Investors" [9]. The research firm (closed in 2011) focused on analyzing a company's performance on environmental, social, and strategic governance issues for such clients as institutional investors, foundations and endowments, and pension funds. In the 2004 report, the research firm discussed the issue of "Agent Orange Concerns beyond US Vietnam Veterans" [9]. Included in the discussion was the statement: "Soldiers stationed on Guam who handled Agent Orange have become ill and symptoms of TCDD (dioxin) poisoning are apparent in the general population of the island as well. TCDD soil contamination from Agent Orange handling has been measured up to 1900 ppm in some areas of Andersen Air Force Base on Guam" [9]. The source of the information was the newspaper article "Sick Vets Report on Agent Orange" published on 17 June 2003 in the Pacific Daily News, with the analytical data from the 2002 ATSDR Report [5, 9].

In a 5 June 2006 letter from Congresswomen Madeleine Z. Bordallo, Guam, to the Deputy Under Secretary of Defense (I\&E), the following comments were made: "I am concerned with continued reports from Vietnam-era veterans who served on Andersen AFB that testify to both the use of rainbow defoliants around the Andersen AFB airfields and the storage and handling of the defoliants on the base. The DOD findings and the information previously provided on this subject are inconsistent with the 
accounts to these veterans... I respectively request that you undertake a new and more thorough search of DOD records and, and if necessary, conduct a detailed investigation of alleged use and storage of rainbow defoliants at Andersen AFB during both the Korean War and the Vietnam War" [10].

Despite the evidence presented by ATSDR and the EPA/USAF Records of Decisions, extensive media coverage continued. "Agent Orange on Guam Confirmed" was the headline of an article dated 25 October 2005; "Another Case Confirms Agent Orange on Guam" dated 26 May 2009; and "Veterans: We Sprayed Agent Orange on Guam" dated 10 May 2010. All three of the stories were written by the same reporter and published in the Marianas Variety-Guam Edition, Micronesia's leading newspaper [11]. The first article discussed the decision by the Department of Veterans Affairs Board of Veterans Appeals that a veteran who had served on Guam during the Vietnam War was entitled to service connection for diabetes mellitus secondary to herbicide exposure [1]. As the DVA identified more diseases associated with exposure to Agent Orange, the number of claims from veterans stationed on Guam has increased. The 16 September 2011 article "Rule change helps veterans: more diseases included in coverage" noted that "about 900 Guam residents - including veterans and wives of deceased veterans - are collecting compensation for Agent Orange exposure" [12]. The article did not provide a source of the information other than statements by veterans.

\section{Veterans' Allegations}

As noted, there are numerous Internet sites in which US veterans stationed at Andersen AFB during the Vietnam Era described how they were allegedly exposed to Agent Orange [2, 11, 12]. These scenarios included:

1. Since Agent Orange and other tactical herbicides were allegedly routinely used at Andersen AFB from December 1966 through December 1970, many veterans alleged that they were frequently subjected to the spray drift;

2. One of the alleged routes of exposure was that associated with military occupational duties such as aircraft maintenance specialists required to work in and around the airdrome, the perimeter of which was continuously brown due to herbicide spraying;

3. One veteran claimed that he was responsible for transferring the Agent Orange from drums to 750-gallon trailers and then mixing with diesel fuel before spraying perimeter security fencing, fuel pipelines, and around bulk storage units;

4. Some veterans claimed that they were responsible for off-loading Agent Orange that arrived by ship at Apra Harbor, Naval Base Guam, and transporting the herbicide to aircraft at Andersen AFB for flights directly to Vietnam;

5. One veteran recalled seeing drums in open storage at the edge of the base which contained herbicides; and,

6. One veteran recalled handling $\sim 25$ kilogram bags of Agent White and Agent Blue and mixing these powered herbicides with JP4, water, and heavy oil. The veteran claimed he sprayed these herbicides from September 1968 to June 1978.

\section{Tactical and Commercial Herbicides}

Much confusion exits over the differences between commercial herbicides purchased by the individual agencies of the Department of Defense, and the tactical herbicides that were purchased by the Defense Supply Agency for use in Vietnam [13]. In either case, the DOD strictly controlled the use of all commercial and tactical herbicides used. This included any research, field evaluation, personnel certification, procurement, and application. Formulation of the tactical herbicide Agent Orange contained only the active ingredients of $2,4-\mathrm{D}$ and $2,4,5-\mathrm{T}$ as the n-butyl formulation with no diesel fuel or other solvents added. The Army Chemical Corps specified the formulations of tactical herbicides. The tactical herbicide Agent Orange was produced solely for the Department of Defense and was managed under the tight control of the US Army Chemical Corps and the United States Air Force Logistics Command. The Army Chemical Corps and the United States Air Force Logistics Command kept extensive records on all movement and shipment of tactical herbicides e.g., DD Form 173/2 (Joint 
Message Form Authorizing Shipments) and DD Form 250/250a (Materiel Inspection and Receiving Report), and those records were in the archives that were searched [13].

The Department of Defense used commercial herbicides to control vegetation along roads, landing strips, fence lines, power lines, and the grounds around airdromes. Internal Department of Defense guidance now and during the Vietnam War Era allowed only the use of "commercially available registered herbicides" on US military installations applied by "licensed applicators". Licensed applicators could only apply commercial herbicides - they were not authorized to apply tactical herbicides. Commercially available herbicides had to meet USDA's regulatory requirements (now the US Environmental Protection Agency, EPA), and had to comply with the Federal Insecticide, Fungicide and Rodenticide Act (FIFRA) [13].

Inside the Department of Defense, the Armed Forces Pest Control Board (AFPCB, now Armed Forces Pest Management Board, AFPMB) approved all commercial herbicides and other pesticides that were to be used on US military installations, including those in other countries. Indeed, the use of commercial herbicides, including commercial formulations of 2,4-D and 2,4,5-T, on a US military installation outside the Continental US also was required to meet the US Department of State's Agency for International Development guidelines, ensuring both quality of product, its approved uses, and its distribution. Thus, commercial herbicides were required to meet AFPMB standards for safety (both human and environmental), stability, and efficacy. Certification was required of all applicators (military or civilian) and purchases were through the Installation's Facility Manager or Base Engineer [13].

\section{$5 \quad$ Criteria for Validating Agent Orange Sites}

In October 2012, Compensation Service, Veterans Benefits Administration contracted for 23 Investigative Reports, i.e., The Agent Orange Investigation Report Series. In addition to the Reports, a supporting project was initiated on "Development of an Archival Directory of Agent Orange Documents." Thus, every Investigative Report was required to be supported by archival information [14]. This was intended to remove any bias as to whether a site received tactical herbicides and whether the site was used for tests and evaluations, actual spraying programs, or for storage or disposal. Most importantly, the time frame of the involvement of the tactical herbicide(s) must have been during or immediately after the Vietnam War, and there must be some evidence (other than an associated disease) that the veteran dealt with a tactical herbicide, rather than a commercial herbicide.

To validate that a tactical herbicide, e.g., Agent Orange was shipped, used, stored, or buried at a site, and hence potential exposure could have occurred, one or more of the following criteria were required:

1. Department of Defense form 173/2, Message Transmission of MILSTRIP (Military Standard Requisition and Issues Procedures) Transactions Form. The originator of this form was the Defense Logistics Agency and it was used in providing supply/logistics; all shipments of tactical herbicides to Southeast Asia and elsewhere were required to have DD form $173 / 2$;

2. Department of Defense form 250/250a, Materiel Inspection and Receiving Report. This form identified the agency placing the order, name of the prime contractor, the manufacturer or warehouse to which it was shipped from, and the location shipped to. The form also identified the stock and/or part number and description of the articles;

3. Department of the Army form 2496, Disposition Form. The form required a reference or office symbol, Subject box, and to, from, and date. The form was used by the US Army for the Survey of Chemical Hazards, or for the identification and quantification of pesticides pending their disposal;

4. Any historical document(s) found in the National Archives, including correspondence, that described the presence of Agent Orange or other tactical herbicides at a specific site;

5. Technical reports published by a government agency that describe the testing, evaluation, or disposal of a tactical herbicide at a specific site;

6. It must be a location/site where Vietnam-era military personnel were participants directly or indirectly in the activities involving Agent Orange or other tactical herbicides; and/or,

7. A credible document maintained by the Vietnam-era veteran that can be authenticated [14].

What was not acceptable for the validation of exposure to Agent Orange or other tactical herbicides were the following: 1) the presence of a disease or illness as identified by VA as associated with Agent 
Orange exposure; 2) an undocumented statement(s) by the Vietnam-era veteran or veterans; 3) anonymous unverified Internet sources; 4) News media reports without supporting authenticated documentation; and/or 5) allegations of presence or use by residents without authenticated documentation [14].

\section{$6 \quad$ Evaluation and Documentation and Allegations on Agent Orange}

A 12-month extensive search conducted of military records in NARA and other US government record repositories could not verify that Agent Orange or other tactical herbicides had ever been transported, stored, or used on Andersen AFB or elsewhere on Guam. There were no DD forms 173/2 or 250/250a found in the archives identifying Guam, although such forms were present for many other locations. The forms discovered indicated that tactical herbicides went directly from their ports of embarkation directly to Vietnam without deviation. There were no technical reports or correspondence from the US Army Chemical Corps or Air Force Logistics Command indicating that tactical herbicides were tested, used, or stored on Guam. As previously noted, the Andersen AFB Base Restoration Program was contacted in 2009, and the Program Coordinator reported that a Freedom of Information Act (FOIA) had been received and they were not able to find any written records of storage or use of Agent Orange at Andersen AFB. The following observations were critical to understanding why no Agent Orange exposure occurred on Guam:

1. The Department of Defense through the Armed Forces Pest Control Board (AFPCB) strictly controlled all herbicides available on the military supply list. Agent Orange was not a USDA registered herbicide or an AFPCB approved herbicide and thus was NOT APPROVED for purchase or use by the Base or Installation Engineer [14];

2. The observations of 55-gallon drums adjacent to the runway confirmed the logistical storage of petroleum-based products including oils, lubricants and solvents. Herbicide containers were required to be placed in approved pesticide storage facilities. Every US Military Installation had strict requirements for the storage of pesticides. The Department of Defense issued criteria to plan and design facilities to store pesticides consistent with the current pesticide regulatory guidance [15]. Thus, pesticides would not have been placed in the open storage;

3. Training and certification of pesticide applicators have been considered as the most essential elements of the military pest control program and have been required of personnel handling pesticides since 1957. High standards were maintained through this training requirement and assure that pest control supervisory and operator personnel had and continued to have a high level of competency to apply materials effectively and safely [16]. Thus, only certified applicators would have been involved in the spraying of herbicides within the airdrome of Andersen AFB;

4. The commercial herbicides Amitrole and Bromacil were routinely used to control vegetation adjacent to runways and storage areas. These materials were wettable powders and applied in water [15]. The applicators were certified, under the supervision of the Base Engineer, and trained to apply the herbicides safely. Because they were wettable powders applied in water, no negligible drift would occur and thus maintenance and air crews were unlikely to be exposed.

5. Typhoon Karen in 1962 created a massive amount of damage and much of the debris was placed in landfills [4]. That debris would probably have included materials such as electrical transformers containing dioxins and furans. The burning of wastes also created dioxins and furans. ATSDR reported dioxins as TEQ. Dioxins are generally found in mixtures containing several kinds of dioxins and dioxin-like compounds, e.g., furans, each having its own degree of toxicity. To express the overall toxicity of such a mixture as a single number, the concept of "Toxic Equivalents" has been accepted internationally. The TEQ scheme weighs the toxicity of the less toxic compounds as fractions of the toxicity of the most toxic TCDD. Agent Orange contained one primary dioxin $(2,3,7,8$-TCDD), while the samples from Guam landfills contained 17 different dioxins and furans, 2,3,7,8-TCDD being only a very minor component. Thus, examination of the ATSDR and EPA analytical data (Table 2-3: Surface and Subsurface Results for Dioxins and Explosives of the ATSDR Report) confirmed that such a mix of dioxins 
and furans were not from Agent Orange, but emission sources, and the exposure to such contaminated soils was not a likely pathway for veteran exposure.

\section{$7 \quad$ Evaluation of Allegations on Agent Purple}

Allegations that Agent Purple was produced in 1952-1953, subsequently tested and evaluated in the Continental United States, and then prepositioned in Guam for potential anti-crop use during the Korea Conflict have appeared in numerous publications [2, 7]. Mitchell attributed these allegations to U. S. government records $[18,19]$. After an extensive search and re-evaluation of documents in the National Archives, new documentation was found that clarified the tactical herbicide formulation and the Hourglass MC-1 Aerial Spray System procured in 1952-1953 for the Korean Conflict [20, 21, 22, 23].

The herbicide formulation that was procured for the Korean Conflict was a mixture of $75 \%$ n-butyl 2,4-D and 25\% n-butyl 2,4,5-T [20]. This formulation was used in the evaluation of large capacity spray systems at Eglin AFB, FL in 1953 [21]. Subsequently, 100 units of the MC-1 Hourglass Spray Systems and a large volume (>12,000 55-gal drums) of the 75:25 mixture were prepositioned in Spokane, Washington in 1954, and was never deployed because of the termination of the conflict in Korea in 1954 $[22,23]$. The MC-1 Hourglass Spray Systems were later used in OPERATION RANCH HAND, Vietnam $[23,24]$. Part of the Korean herbicide inventory was purchased by The Dow Chemical Company and reformulated as the Purple formulation, a mixture of $50 \%$ n-butyl 2,4-D, 30\% n-butyl 2,4,5-T and 25\% iso-butyl 2,4,5-T [24]. The remaining inventory of the 75:25 mixture was purchased by another chemical company and reformulated as commercial n-butyl 2,4-D and n-butyl 2,4,5-T [25]. Between December 1961 and March 1965, five chemical companies produced a total of 12,780 55-gal drums of Agent Purple that was subsequently sent directly to South Vietnam (Young, Table 2.2, data from Defense Supply Agency and Air Force Logistics Command records, Ref 24). There were no DD Form 250/250a, Materiel Inspection and Receiving Reports, found in the Archives indicating that Agent Purple was ever shipped to or stored on the Island of Guam.

\section{Conclusions}

The examination of historical records on procurements and shipments of Agents Orange and Purple in the United States National Archives and supporting studies by the Agency for Toxic Substances and Disease Registry and the Environmental Protection Agency failed to support any plausible scenarios presented by Vietnam-era veterans stationed at Andersen Air Force Base or elsewhere on the island of Guam that exposure to Agents Orange or Purple occurred.

Acknowledgement. Portions of this article were based on an Investigative Report on Guam prepared for Compensation Service, United States Department of Veterans Affairs, Washington, DC, Contract: VA-101-12-C-006, June 2013. Thanks to the Staff of the United States National Archives for their assistance in finding new documents related to the procurement of herbicides and operational spray systems obtained during the period of the Korean Conflict.

\section{References}

1. Department of Veterans Affairs, Board of Veterans' Appeals, Docket NO. 02-11 819, Citation No: 0527748, Decision Date: 10/13/05, Archive Date: 10/25/05, Washington DC.

2. J. Mitchell, Poisons in the Pacific: Guam, Okinawa and Agent Orange. The Japan Times, 8 July 2012.

3. K. P. Mora, A 68-year-old Air Force veteran said he sprayed Agent Orange on Guam in '60s,'70s. Published 4:31 p.m. ChT Jan 5, 2017, kmora@guampdn.com

4. Public Affairs, 36th Wing, Andersen Air Force Base, Guam: History of Andersen Air Force Base, 2010. The Official Web Site of Andersen Air Force Base: http://www.andersen.af.mil.

5. ATSDR, Public Health Assessment, Andersen Air Force Base, Yigo, Guam. Summary and Appendix A: Evaluation of Potential IRP Sites at Andersen AFB. Agency for Toxic Substances \& Disease Registry, Department of Health and Human Services, Atlanta GA, 2001. 
6. EPA, EPA Superfund Record of Decision: Andersen Air Force Base, US Environmental Protection Agency Report EPA/ROD/R09-2004/002, EPA ID: GU6571999519, OU 07, YIGO, GU, 1 Dec 2003.

7. L. Evans, Letter from Congressman Lane Evans to Secretary of Defense Rumsfeld, 7 May 2003, RE: Requesting Review of Guam "Public Health Assessment" and details on 30 other locations alleged to be sites where tactical herbicides were used, tested, or stored

8. P. W. Grone, Letter from the Principal Assistant Deputy Under Secretary of Defense (Installations and Environment) to Congressman Lane Evans, 23 September 2003, RE: No records on Guam; Summary of 28 locations on the use of Vietnam-era herbicides, per request.

9. Innovest Strategic Value Advisors, Dow Chemical: Risks for Investors - Uncovering Hidden Value Potential for Strategic Investors. Report prepared by Innovest Strategic Investors, New York, NY, 2004

10.M. Z. Bordallo, Letter to Deputy under Secretary of Defense (I\&E) Philip Grone, 5 June 2006 Requesting New Search of DoD Records on Guam and Agent Orange, 2006.

11.M. V. Cagurangan, Agent Orange on Guam Confirmed; Another Case Confirms Agent Orange on Guam" dated 26 May 2009; and "Veterans: We Sprayed Agent Orange on Guam" dated 10 May 2010. Marianas VarietyGuam, Online Edition.

12.Pacific Daily News, Rule Change Helps Veterans: More Diseases Included in Coverage, Guampdn.com, 16 September 2011.

13.A. L. Young, The History of the US Department of Defense Programs for the Testing, Evaluation, and Storage of Tactical Herbicides. Prepared for the Office of the Under Secretary of Defense (I\&E), 2006 [Available from the Armed Forced Pest Management Board Literature Retrieval System (AFPMB LRS), Accession No. 182581).

14.A. L. Young, K. L. Young, Investigations into Sites Where Agent Orange Exposure to Vietnam-Era Veterans Has Been Alleged. Agent Orange Investigative Report, No. 8, May 2013. Prepared for Compensation Service, Department of Veterans Affairs, Washington DC.

15.Department of Defense, Military Handbook: Design of Pest Management Facilities. Report MIL-HDBK1028/8,31, Supersedes previous handbooks, 31 October 1984. (AFPMB LRS, Accession No. 123220).

16.Department of Defense, Plan for Certification of Pesticide Applicators. Armed Forces Pest Control Board, Forest Glen Section, WRAMC, Washington DC, 1977 (AFPMB LRS, Accession No. 96815).

17.K. G. Wickham, Herbicides, Pest Control Agents, and Disinfectants. Department of the Army Supply Bulletin, SB 3-40, Department of the Army, Washington DC, 1968. (AFPMB LRS, Accession No. 50641).

18.A. L. Young, Ecological Studies on a Herbicide-Equipment Test Area (TA C-52A), Eglin AFB Reservation, Florida. Final Report: Jan 1967 to Nov 1973. Technical Report, AFATL-TR-74-12, Air Force Armament Laboratory, 1974. [Available from Defense Technical Information Center (DTIC), Accession No. AD-780-517].

19.A. L. Young, The History of the US Department of Defense Programs for the Testing, Evaluation, and Storage of Tactical Herbicides. Report prepared for the Office of the Under Secretary of Defense, Washington, DC, Dec 2006. (AFPMB LRS, Accession No. 182581).

20.R. M. Acker, R. W. Hartmeyer, J. E. Heatherly, and W. E. Bullard, Anticrop Aerial Spray Trials, Phase III. Special Report No. 184, US Army Chemical Corps' Biological Laboratories, Camp Detrick, Frederick, Maryland, 15 Feb 1953 (DTIC, Accession No. AD 49572).

21.J. F. Ward, Evaluation of Production Model of Large Capacity Spray System for B-29 and C-119 Aircraft. Technical Report No. 53-33, Air Force Armament Center, Eglin AFB, Florida, 4 Nov 1954. (DTIC, Accession No. AD1763).

22.D. L. Miller, Historian, History of Air Force Participation in the Biological Warfare Program, 1951-1954, Monograph prepare by Historical Division, Office of Information Services, Air Materiel Command, WrightPatterson AFB, Jan 1957. (This document declassified 28 Jun 78, but subject to export control. Available from the DTIC).

23.W. A. Buckingham, Jr. "OPERATION RANCH HAND: The Air Force and Herbicides in Southeast Asia, 19611971", Office of Air Force History, Washington, DC, 1982 (see page 6).

24.A. L. Young, "The History, Use, Deposition, and Environmental Fate of Agent Orange", Springer 2009.

25.M. Fingerhut, L. M. Blade, D. A. Marlow, NIOSH Dioxin Registry Site Visit Report of Rhone-Poulenc, Incorporated, Portland, Oregon, Report No. IWS-117-14, 31 Jan 1984. Prepared by the Industrywide Studies Branch, National Institute for Occupational Safety and Health Center (NIOSH), Cincinnati, OH. (Available from the National Technical Information Service, US Depart of Commerce, Accession No. PB84-240035). 